\title{
AN IN VITRO INVESTIGATION OF ANTIMICROBIAL EFFICACY OF EUPHORBIA HIRTA AND MURRAYA KOENIGII AGAINST SELECTED PATHOGENIC MICROORGANISMS
}

\author{
DIVYA GUPTA ${ }^{1,2}$, MUKESH KUMAR ${ }^{1 *}$, VISHAL GUPTA ${ }^{1}$ \\ ${ }^{1}$ Department of Biotechnology Engineering, Ambala College of Engineering and Applied Research, Ambala, India. ${ }^{2}$ Department of \\ Biological Sciences, BITS, Pilani K K, Birla Goa Campus, Goa, India. Email: mukesh.biotech@gmail.com
}

Received: 02 January 2018, Revised and Accepted: 13 February 2018

\section{ABSTRACT}

Objective: To investigate the solvent-dependent antimicrobial activity and phytochemical analysis of extracts of Euphorbia hirta (leaves and flowers) and Murraya koenigii (leaves), as well as to evaluate the synergistic activity of these medicinal extracts with suitable antibiotic discs and antibiotics susceptibility of selected pathogenic microorganisms.

Methods: The antimicrobial activity of the medicinal extracts was screened through agar well diffusion method and antibiotics susceptibility of selected microorganisms was investigated using disc diffusion method. A combined agar well diffusion and disc diffusion methods were used for the determination of synergistic activities of the extracts with antibiotic discs.

Results: Among the different solvents, ethanol had maximum zone of inhibition against the test pathogens. Ethanolic leaf extracts of $E$. hirta exhibited the highest inhibitory activity against Candida albicans and Staphylococcus aureus with minimum inhibitory concentration value of 12.5 mg/mL and $25.0 \mathrm{mg} / \mathrm{mL}$, respectively. Antimicrobial assay revealed that E. hirta extracts were active against all tested Gram-negative bacteria. However, none of the plant extracts had inhibitory activity against Gram-positive bacterium Propionibacterium acnes. Phytochemical screening for both the extracts from E. hirta revealed the presence of steroid, tannin, terpenoids, carbohydrates, alkaloid, flavonoid, diterpene, and glycoside, whereas $M$. koenigii extract was rich in saponins, protein, steroid, tannin, carbohydrates, alkaloid, flavonoid, and glycoside.

Conclusion: The present study proposes that $E$. hirta and $M$. koenigii extracts are excellent sources of natural bioactive compounds that could be used as potent antimicrobial drugs to counter the emerging problem of antibiotic resistance of pathogenic microorganisms.

Keywords: Euphorbia hirta, Murraya koenigii, Antimicrobial activity, Phytochemical analysis, Minimum inhibitory concentration.

(C) 2018 The Authors. Published by Innovare Academic Sciences Pvt Ltd. This is an open access article under the CC BY license (http://creativecommons. org/licenses/by/4. 0/) DOI: http://dx.doi.org/10.22159/ajpcr.2018.v11i5.24578

\section{INTRODUCTION}

In the present world, there are many infectious and re-emergent diseases that led to the development of a number of antibiotics. The literature reveals that infectious diseases represent the second leading cause of death worldwide. At present, more than 100 types of antibiotics are being widely used to treat various microbial infectious diseases [1]. However, irregular use of these antibiotics has caused the emergence of antibiotic-resistant bacteria, particularly Staphylococcus aureus (MRSA). Moreover, the side effects associated with the widespread use of these antibiotics may have deleterious effects on human organs. Therefore, due to the rising incidences related to multidrug resistance among pathogenic microorganism and the antibiotic side effects, there is a need to find out new antimicrobial sources for the treatment of human diseases [2]. The natural products derived from medicinal plants represent an immense and practically unexploited source of potentially useful bioactive compounds. Plants have been used globally in the treatment of various infectious diseases as a traditional medicine for thousands of years. Currently, a number of pharmaceutical companies are spending a lot of money and time to develop cost-effective plantderived natural drugs [3]. Plants are the rich source of many secondary plant metabolites, such as tannins, terpenoids, alkaloids, flavonoids, phenols, and quinines [4-6]. These phytochemicals are thought to play an important role in the treatment of urinary tract infections, gastrointestinal disorders, respiratory diseases, and cutaneous infections [7]. There are about 500,000 plant species around the world, and only one percent of their phytochemicals have been evaluated [8]. Therefore, the plants hold great potential for the discovery of novel bioactive compounds that could prove alternative to the synthetic drugs or antibiotics.
Euphorbia is the largest genus of the family Euphorbiaceae, which includes about 1600 species. Many species of this group are used in traditional medicines and have been intensively used for phytochemical investigation and antimicrobial properties. These species are known to contain various antimicrobial compounds, namely, flavonoids, triterpenoids, alkanes, amino acids, and alkaloids [9]. Euphorbia hirta is a pantropical weed, possibly native to India. It is a hairy herb that grows in open grasslands, roadsides, and pathways. E. hirta is broadly used as a medicinal herb as it possesses antibacterial, anthelmintic, antiasthmatic, sedative, antispasmodic, antifertility, antifungal, and antimalarial properties [10].

Murraya koenigii, commonly known as curry leaf or Kari patta in Indian dialects, belongs to Family Rutaceae that includes more than 150 genera and 1600 species [11]. M. koenigii is a small evergreen tree native of India and also found in Sri Lanka and other South Asian countries. Different parts of M. koenigii are used in folkloric medicine for the treatment of various diseases. This plant is known to possess antioxidative, cytotoxic, antimicrobial, antibacterial, antiulcer, positive inotropic, and cholesterolreducing activities $[12,13]$. In view of the significant medicinal importance of these plant species, the present study was undertaken with an objective of analysis of phytochemicals and antimicrobial properties of $E$. hirta and $M$. koenigii against selected pathogenic microorganisms, which might be a promising source of new isolates capable of combating the problem of antibiotic resistance among the microorganisms in the future.

\section{METHODS}

\section{Collection of plant samples}

Medicinal plant samples of E. hirta (leaves and flowers) and M. koenigii (leaves) were collected from different areas of Ambala district, Haryana, 
India. After the collection, the plant material was washed with distilled water and shade-dried on paper towels in the laboratory at $37^{\circ} \mathrm{C}$.

\section{Test microorganisms}

The microorganisms used in the present study, Candida albicans, Escherichia coli, Pseudomonas aeruginosa, Propionibacterium acne, and $S$. aureus, were obtained from IMTECH, Chandigarh, India. The microbial cultures were maintained in culture broth (Himedia) at $37^{\circ} \mathrm{C}$ and on agar (Himedia) plates at $4^{\circ} \mathrm{C}$.

\section{Extract preparation}

The extraction was performed according to the method of Cheesbrough [14]. The collected plant materials were finely powders using a blender. Five gram of powdered plant material was taken in four $100 \mathrm{~mL}$ conical flasks and $50 \mathrm{~mL}$ of each solvent, namely, water, ethanol, petroleum ether, and chloroform:methanol (1:1) was added separately in the concerned flasks. The sealed flasks were kept in a rotary shaker for 2 days, after which the extract was filtered through muslin cloth followed by Whatman No. 1 filter paper. The solvent from aqueous extract was removed through lyophilization, while the ethanol, petroleum ether, and chloroform:methanol (1:1) extracts were kept in a water bath at $65^{\circ} \mathrm{C}$ to evaporate the solvent. Finally, the residues were collected and dissolved in sterile distilled water (for aqueous extract) and $70 \%$ acetone (others). Each extract was stored at $4{ }^{\circ} \mathrm{C}$ in the refrigerator until use. Further, all the plant extracts were screened for their antimicrobial activity.

\section{Determination of antimicrobial activity}

The antimicrobial activity of each crude extract was determined using the agar well diffusion method Rojas et al. [15]. After autoclaving, the medium was cooled at $45-50^{\circ} \mathrm{C}$ and poured into flat-bottomed Petri dishes ( $90 \mathrm{~mm}$ in diameter) to obtain a depth of nearly $4 \mathrm{~mm}$. The agar media was allowed to cool and solidify at room temperature, and the plates were pre-incubated at $35^{\circ} \mathrm{C}$ for $18-20 \mathrm{~h}$ to confirm sterility. About $100 \mu \mathrm{L}$ of the test inoculum was uniformly spread on the surface of the solidified agar using a sterile spreader. Four equidistant wells of $8 \mathrm{~mm}$ in diameter and $3 \mathrm{~mm}$ in depth were made on the agar plate. About $100 \mu \mathrm{L}$ of the plant extracts was filled in the wells. The bacterial agar plates were incubated aerobically for $24 \mathrm{~h}$ at $37^{\circ} \mathrm{C}$ except for P. acne which was incubated under anaerobic condition. The fungal $C$. albicans plates were incubated for $48 \mathrm{~h}$ at $30^{\circ} \mathrm{C}$. Antimicrobial activity was determined by measuring the diameters of the zones of inhibition in $\mathrm{mm}$. The test was performed in triplicates with controls ( $70 \%$ acetone).

Determination of minimum inhibitory concentration (MIC) and minimum bactericidal/fungicidal concentration (MBC/MFC)

MIC of E. hirta and M. koenigii extracts was determined through broth dilution method using 96 well plates $[16,17]$. The wells of each row were filled with $0.5 \mathrm{~mL}$ sterilized nutrient broth for E. coli and P. aeruginosa, Mannitol salt broth for $S$. aureus and malt extract broth for $C$. albicans followed by the addition of $0.5 \mathrm{~mL}$ of a mixture of culture medium. Each well-received plant extract, serially diluted to create a concentration ranging from 50 to $3.125 \mathrm{mg} / \mathrm{mL}$. The plates were incubated under aerobic conditions at $37^{\circ} \mathrm{C}$ for $24 \mathrm{~h}$ (for bacteria) and $25^{\circ} \mathrm{C}$ for $48 \mathrm{~h}$ (for fungus). The lowest concentration (highest dilution) of the extract that resulted in no visible growth (no turbidity) in the first $24 \mathrm{~h}$ as compared with the control tubes was considered as an initial MIC. The dilutions that had no turbidity were further incubated at $37^{\circ} \mathrm{C}$ for $24 \mathrm{~h}$. The lowest concentration that exhibited no visible turbidity after a total incubation period of $48 \mathrm{~h}$ was considered as the final MIC. MBC/MFC value was determined by subculturing the test dilution that showed no visible turbidity on to freshly prepared respective agar media. The plates were incubated further at $37^{\circ} \mathrm{C}$ for $42 \mathrm{~h}$. The highest dilution that yielded no single bacterial colony on the nutrient agar plates was taken as MBC.

The antimicrobial susceptibility pattern of tested microorganisms The antimicrobial susceptibility pattern of tested microorganisms was determined using disc diffusion method [18]. The freshly prepared and cooled medium was poured into flat-bottomed Petri dishes, and
$100 \mu \mathrm{L}$ of the tested inoculum was evenly spread on the surface of the solidified agar media using a sterile spreader. Suitable antibiotics/ antifungal discs were placed on the agar plates and incubated for $24 \mathrm{~h}$. The antimicrobial susceptibility was determined by measuring the diameters of inhibition zone ( $\mathrm{mm}$ ).

\section{Synergistic antimicrobial activities of plant extracts with antibiotics}

For the synergistic activities of plant extracts with antibiotics (exhibiting the largest zone of inhibition against respective microorganism), levofloxacin (for Gram-negative bacteria) and lincomycin (for Grampositive bacteria) were used with extracts. About $0.1 \mathrm{~mL}$ of the tested inoculum was evenly spread on the surface of the solidified agar media using a sterile spreader. After a few minutes, a well of $8 \mathrm{~mm}$ (diameter) and $3 \mathrm{~mm}$ (depth) was made in the mid of agar plate and was filled with $100 \mu \mathrm{L}$ of the plant extract. The antibiotic disc was placed on the top of the well and the plates were incubated at $35^{\circ} \mathrm{C}$ for $18-20 \mathrm{~h}$. The synergistic activity was obtained by measuring the diameters of inhibition zones ( $\mathrm{mm}$ ) and further comparing with inhibition zones of the extracts and antibiotics against respective microorganisms [19].

\section{Phytochemical analysis}

Phytochemical analysis of the tested plants was carried out by dissolving the extracts in respective solvents. The extracts were analyzed for the presence of alkaloids, flavonoids, saponins, tannins, carbohydrates, terpenoids, protein, glycosides, diterpenes, and steroids using the standard procedures [20-22]

\section{Statistical analysis}

The data were analyzed by using simple arithmetic means of the different extracts and the SE was compared with the controls.

\section{RESULTS AND DISCUSSION}

Determination of antimicrobial activity of different extracts

In the present study, the antimicrobial activity of E. hirta and M. koenigii extracts prepared in different solvents was determined against $E$. coli, $P$. aeruginosa (Gram-negative), $P$. acnes, $S$. aureus (Gram-positive), and fungus $C$. albicans. The results presented in Table 1 revealed that among the four solvents, ethanol proved to be the best one with the strongest and broadest action spectrum against the test microorganisms. The differential behavior of solvents on antimicrobial activity might be due to differences in their polarities. Antimicrobial compounds such as flavonoids and terpenoids are polar constituents and are difficult to be extracted using non-polar solvent systems. Ethanol being the most polar of the solvents used would have facilitated better release of these antimicrobial compounds from the extracts. The present results are also corroborated by the previous reports suggesting ethanol as a preferential solvent in determining the antimicrobial potential of medicinal plants [7,23-25]. Because of the maximum inhibitory potential of the ethanol, all further experiments were conducted with ethanolic extracts.

Both ethanolic extracts of $E$. hirta displayed significant antibacterial activity against all test microorganisms except $P$. acnes. Maximum activity was observed against $C$. albicans $(17 \mathrm{~mm})$ and $S$. aureus (13 mm), whereas moderate activity was obtained against Gramnegative bacteria. The results obtained in this study are in close proximity to the findings of previous reports related to the antimicrobial properties of the E. hirta against various microorganisms [26-30]. In comparison, the ethanolic extract of $M$. koenigii inhibited the growth of only E. coli, C. albicans, and S. aureus, whereas no antibacterial activity was displayed against $P$. aeruginosa and $P$. acnes. Maximum inhibition was observed against $C$. albicans $(12 \mathrm{~mm})$ followed by $S$. aureus ( $9 \mathrm{~mm})$. There are also previous reports supporting the current results regarding the antimicrobial potential of $M$. koenigii $[24,31]$. Since all the extracts exhibited maximum activity against $C$. albicans, it could be concluded that these extracts may find one of the major applications in the treatment of skin and diaper rash, genital infection, and other Candida-associated diseases. 
Determination of MIC and MBC/MFC

The inhibitory activity of all ethanolic extracts varied significantly against the tested isolates with MIC value ranging from 12.5 to $50 \mathrm{mg} / \mathrm{mL}$. The least MIC was produced by the leaf extract of $E$. hirta on C. albicans $(12.5 \mathrm{mg} / \mathrm{mL})$, while maximum value $(50 \mathrm{mg} / \mathrm{mL})$ was exhibited by the same extract against $P$. aeruginosa. The extracts of E. hirta (flower) and M. koenigii produced the least MIC $(25 \mathrm{mg} / \mathrm{mL})$ against $C$. albicans and $S$. aureus while maximum MIC $(50 \mathrm{mg} / \mathrm{mL})$ was against $E$. coli and P. aeruginosa (Table 2). Following the MIC, the $\mathrm{MBC} / \mathrm{MFC}$ was also determined and the results are depicted in Table 3. The MBC of all the extracts was found to be $50 \mathrm{mg} / \mathrm{mL}$ for $E$. coli, $P$. aeruginosa, and $S$. aureus. MIC value equal to MBC value represents their bactericidal activity against respective microorganisms. The MIC and MBC values for E. coli (E. hirta flowers and M. koenigii) and P. aeruginosa (both extracts of $E$. hirta) were found to be equal. The MFC of E. hirta (leaves) for C. albicans was found to be $25 \mathrm{mg} / \mathrm{mL}$ which is 2 times higher than its MIC value, whereas it was $50 \mathrm{mg} / \mathrm{mL}$ for $E$. hirta (flowers) and M. koenigii extracts.

Antimicrobial susceptibility pattern of test microorganism

The antimicrobial susceptibility pattern of Gram-positive bacteria is given in Table 4. The strain S. aureus exhibited maximum zone of inhibition against antibiotic lincomycin $(29 \mathrm{~mm})$ and the minimum against tetracycline $(21 \mathrm{~mm})$. On the contrary, P. acnes was found to be resistant to cloxacillin and lincomycin. Its growth was inhibited maximally against cefotaxime $(30 \mathrm{~mm})$, whereas the lowest zone of $20 \mathrm{~mm}$ was observed against co-trimoxazole. In case of Gram-negative bacteria, E. coli was found to be susceptible maximally to levofloxacin and minimally to aztreonam exhibiting inhibition zones of $35 \mathrm{~mm}$ and $15 \mathrm{~mm}$, respectively. P. aeruginosa was found to be resistant to

Table 1: Antimicrobial activity of E. hirta and M. koenigii extracts against tested microorganisms

\begin{tabular}{|c|c|c|c|c|c|c|c|}
\hline \multicolumn{3}{|c|}{ Extract nature and solvent system } & \multicolumn{2}{|c|}{ Gram-negative bacteria } & \multirow{2}{*}{$\begin{array}{l}\text { Fungus } \\
\text { C. albicans (mm) }\end{array}$} & \multicolumn{2}{|c|}{ Gram-positive bacteria } \\
\hline Plants & Parts used & Solvent used & E. $\operatorname{coli}(\mathrm{mm})$ & P. aeruginosa $(\mathrm{mm})$ & & P. acnes (mm) & S. aureus (mm) \\
\hline \multirow[t]{3}{*}{ E. hirta } & Leaves & Aqueous & $6 \pm 0.4$ & NA & $12 \pm 0.3$ & NA & $3 \pm 0.3$ \\
\hline & & Ethanol & $9 \pm 0.2$ & $4 \pm 0.3$ & $17 \pm 0.1$ & NA & $13 \pm 0.2$ \\
\hline & & Petroleum ether & NA & NA & NA & NA & NA \\
\hline \multirow[t]{4}{*}{ E. hirta } & Flower & Aqueous & NA & NA & NA & NA & NA \\
\hline & & $\mathrm{C}: \mathrm{M}$ & NA & NA & NA & NA & NA \\
\hline & & Ethanol & $6 \pm 0.3$ & $4 \pm 0.1$ & $15 \pm 0.4$ & NA & $11 \pm 0.5$ \\
\hline & & Petroleum ether & NA & NA & NA & NA & NA \\
\hline \multirow[t]{4}{*}{ M. koenigii } & Leaves & Aqueous & NA & NA & $5 \pm 0.3$ & NA & $2 \pm 0.3$ \\
\hline & & $\mathrm{C}: \mathrm{M}$ & NA & NA & $4 \pm 0.2$ & NA & $4 \pm 0.3$ \\
\hline & & Ethanol & $6 \pm 0.4$ & NA & $12 \pm 0.2$ & NA & $9 \pm 0.4$ \\
\hline & & Petroleum ether & NA & NA & $3 \pm 0.2$ & NA & $2 \pm 0.2$ \\
\hline
\end{tabular}

NA: No activity exhibited by extract against microorganism, C:M: Chloroform: methanol (1:1). ${ }^{*} \mathrm{~mm}$ : Diameter of zone of inhibition in millimeter. E. hirta: Euphorbia hirta, M. koenigii: Murraya koenigii, E. coli: Escherichia coli, P. aeruginosa: Pseudomonas aeruginosa, C. albicans: Candida albicans, P. acnes: Propionibacterium acnes, S. aureus: Staphylococcus aureus

Table 2: MIC of the different plant extracts against tested microorganisms

\begin{tabular}{|c|c|c|c|c|c|}
\hline Microorganism/plants & Concentration $(\mathrm{mg} / \mathrm{mL})$ & C. albicans & E. coli & S. aureus & P. aeruginosa \\
\hline \multirow[t]{5}{*}{ E. hirta (leaves) } & 50.0 & NG & NG & NG & NG \\
\hline & 25.0 & NG & NG & NG & $\mathrm{G}$ \\
\hline & 12.50 & NG & $\mathrm{G}$ & $\mathrm{G}$ & $\mathrm{G}$ \\
\hline & 6.25 & G & $\mathrm{G}$ & $\mathrm{G}$ & $\mathrm{G}$ \\
\hline & 3.125 & $\mathrm{G}$ & $\mathrm{G}$ & $\mathrm{G}$ & $\mathrm{G}$ \\
\hline \multirow{3}{*}{ E. hirta (flowers) } & 50.0 & NG & NG & NG & NG \\
\hline & 25.0 & NG & G & NG & G \\
\hline & 6.25 & $\mathrm{G}$ & $\mathrm{G}$ & $\mathrm{G}$ & $\mathrm{G}$ \\
\hline \multirow[t]{4}{*}{ M. koenigii } & 50.0 & NG & NG & NG & - \\
\hline & 25.0 & NG & G & NG & - \\
\hline & 12.50 & $\mathrm{G}$ & $\mathrm{G}$ & $\mathrm{G}$ & - \\
\hline & 6.25 & $\mathrm{G}$ & $\mathrm{G}$ & $\mathrm{G}$ & - \\
\hline
\end{tabular}

MIC: Minimum inhibitory concentration, E. hirta: Euphorbia hirta, M. koenigii: Murraya koenigii

Table 3: MBC/MFC of different plant extracts against tested microorganisms

\begin{tabular}{|c|c|c|c|c|c|}
\hline Microorganism/plants & Concentration $(\mathrm{mg} / \mathrm{mL})$ & C. albicans & E. coli & S. aureus & P. aeruginosa \\
\hline \multirow[t]{4}{*}{ E. hirta (leaves) } & 50.0 & $N G$ & NG & $N G$ & $\mathrm{NG}$ \\
\hline & 25.0 & NG & $\mathrm{G}$ & $\mathrm{G}$ & $\mathrm{G}$ \\
\hline & 12.50 & $\mathrm{G}$ & $\mathrm{G}$ & $\mathrm{G}$ & $\mathrm{G}$ \\
\hline & 6.25 & $\mathrm{G}$ & $\mathrm{G}$ & $\mathrm{G}$ & $\mathrm{G}$ \\
\hline \multirow{3}{*}{ E. hirta (flowers) } & 50.0 & $N G$ & NG & $N G$ & NG \\
\hline & 25.0 & $\mathrm{G}$ & $\mathrm{G}$ & $\mathrm{G}$ & $\mathrm{G}$ \\
\hline & 12.50 & $\mathrm{G}$ & $\mathrm{G}$ & $\mathrm{G}$ & G \\
\hline \multirow[t]{4}{*}{ M. koenigii } & 50.0 & $N G$ & NG & NG & - \\
\hline & 25.0 & $\mathrm{G}$ & $\mathrm{G}$ & $\mathrm{G}$ & - \\
\hline & 12.50 & $\mathrm{G}$ & $\mathrm{G}$ & $\mathrm{G}$ & - \\
\hline & 3.125 & $\mathrm{G}$ & $\mathrm{G}$ & $\mathrm{G}$ & - \\
\hline
\end{tabular}

MBC: Minimum bactericidal concentration, MFC: Minimum fungicidal concentration, E. hirta: Euphorbia hirta, M. koenigii: Murraya koenigii 
aztreonam, ceftazidime, and cefotaxime. However, the maximum inhibition zone of $30 \mathrm{~mm}$ of $P$. aeruginosa was observed against levofloxacin (Table 5). On the contrary, the fungus $C$. albicans was resistant to all the tested antibiotics (Table 6).

Synergistic antimicrobial activity of different extracts with antibiotics

Synergistic activity of all extracts (E. hirta and M. koenigii) with selected antibiotics (with maximum inhibition) was determined to observe any effect of the collective action on the antimicrobial efficiency. The results presented in Table 7 revealed that combination of leaf extract of E. hirta with levofloxacin instigated a slight increase in the inhibition zone $(38 \mathrm{~mm})$. However, there was no synergistic effect of the combination of E. hirta (flower) and M. koenigii extracts with the antibiotic levofloxacin

Table 4: Antibiotic susceptibility pattern of Gram-positive bacteria

\begin{tabular}{llll}
\hline Antibiotics & $\begin{array}{l}\text { Concentration } \\
(\boldsymbol{\mu g})\end{array}$ & $\begin{array}{l}\text { S. aureus } \\
(\mathbf{m m})\end{array}$ & $\begin{array}{l}\text { P acne } \\
(\mathbf{m m})\end{array}$ \\
\hline Co-trimoxazole & 25.0 & 27 & 20 \\
Cloxacillin & 1.0 & 24 & $\mathrm{NA}$ \\
Lincomycin & 2.0 & 29 & $\mathrm{NA}$ \\
Cefuroxime & 30.0 & 23 & 22 \\
Cefotaxime & 30.0 & 25 & 30 \\
Tetracycline & 30.0 & 21 & 27 \\
\hline
\end{tabular}

NA: No activity, S. aureus: Staphylococcus aureus, P. acnes: Propionibacterium acnes

Table 5: Antibiotic susceptibility pattern of Gram-negative bacteria

\begin{tabular}{llll}
\hline Antibiotics & $\begin{array}{l}\text { Concentration } \\
(\boldsymbol{\mu g})\end{array}$ & $\begin{array}{l}\text { E. coli } \\
(\mathbf{m m})\end{array}$ & $\begin{array}{l}\text { P. aeruginosa } \\
(\mathbf{m m})\end{array}$ \\
\hline Levofloxacin & 5.0 & 35 & 30 \\
Aztreonam & 30.0 & 15 & $\mathrm{NA}$ \\
Amikacin & 30.0 & 26 & 28 \\
Imipenem & 10.0 & 27 & 26 \\
Ceftazidime & 30.0 & 16 & $\mathrm{NA}$ \\
Cefotaxime & 30.0 & 21 & $\mathrm{NA}$ \\
\hline
\end{tabular}

NA: No activity, E. coli: Escherichia coli, P. aeruginosa: Pseudomonas aeruginosa

Table 6: Antibiotic susceptibility pattern of fungus

\begin{tabular}{lll}
\hline Antibiotics & Concentration $(\boldsymbol{\mu g})$ & C. albicans \\
\hline Nystatin & 50.0 & NA \\
Clotrimazole & 10.0 & NA \\
Miconazole & 30.0 & NA \\
Ketoconazole & 50.0 & NA \\
\hline
\end{tabular}

NA: No activity, C. albicans: Candida albicans on Gram-negative bacteria E. coli and P. aeruginosa. On the other hand, the combination of antibiotic lincomycin with all extracts, particularly $E$. hirta had much higher effect on the growth of Gram-positive bacterium $S$. aureus as witnessed by the increase in the diameter of the zone of inhibition (36 mm).

\section{Phytochemical analysis of the different extracts}

Freshly prepared ethanolic extracts of E. hirta and M. koenigii were subjected to phytochemical analysis for the presence of various constituents (primary and secondary metabolites) responsible for the antimicrobial properties. Phytochemical screening of $E$. hirta extracts revealed the presence of steroid, tannin, terpenoid, carbohydrate, alkaloid, flavonoid, diterpene, and glycoside, while saponin and protein were present only in case of M. koenigii. However, this extract was devoid of terpenoid and diterpene (Table 8). The phytochemicals observed in these extracts have been reported to possess medicinal properties and physiological activity. Flavonoids are characterized by the presence of antibacterial, antioxidant, antidiarrheal, anti-inflammatory, antiallergic, antimutagenic, and vasodilatory properties [31,32]. Saponins are known to possess hypocholesterolemic and antidiabetic properties, while steroids and triterpenoids exhibit analgesic properties [33- 35]. The presence of biologically important phytochemicals in the E. hirta and $M$. koenigii as reported in this study contribute toward their medicinal relevance, and therefore, suggests potential sources for valuable natural drugs.

\section{CONCLUSION}

Evaluation of antimicrobial properties and phytochemical analysis of medicinal plant species possessing pharmacological properties is essential to exploit them as a source of potent natural drugs. In the present study, three medicinal plant species were analyzed for their antimicrobial properties against selected pathogenic microorganisms in different solvents and were screened for the presence of various phytochemical compounds. On the basis of the results obtained, the present work concludes that the highest inhibitory activity of all the plant species was found in ethanol extract as compared to other solvents. On the basis of the antimicrobial study, it was revealed that leaf extract of $E$. hirta exhibited maximum antimicrobial activity against all tested pathogens except $P$. acnes. The other extracts were also found to be inhibitory, but the effect was less pronounced as compared to the leaf extract of E. hirta. Further, both the extracts of E. hirta had similar phytochemical constituents, but $M$. koenigii had variation in its phytochemical compounds with the presence and or absence of some compounds. The occurrence of different secondary metabolites, namely, steroid, tannin, terpenoid, carbohydrate, alkaloid, flavonoid, diterpene, glycoside, and saponin were supposed to be responsible for the antimicrobial properties of E. hirta and M. koenigii and confirmed their antimicrobial efficiency against selected pathogens. Hence, the results of this study apparently specify that E. hirta and M. koenigii could be used as potent antimicrobial drugs of natural origin capable of

Table 7: Synergistic activity of the different plant extracts with selected antibiotics

\begin{tabular}{|c|c|c|c|c|c|c|}
\hline Plant & $\begin{array}{l}\text { Z.O.I of } \\
\text { plant }(\mathrm{mm})\end{array}$ & М.O. & Antibiotic & $\begin{array}{l}\text { Z.O.I of } \\
\text { antibiotic (mm) }\end{array}$ & $\begin{array}{l}\text { Concentration of } \\
\text { antibiotic }(\mu \mathrm{g} / \mathrm{disc})\end{array}$ & $\begin{array}{l}\text { Z.O.I as synergistic } \\
\text { activity }(\mathrm{mm})\end{array}$ \\
\hline \multicolumn{7}{|l|}{ Gram-negative bacteria } \\
\hline \multirow{2}{*}{ E. hirta (leaves) } & $9 \pm 0.2$ & E. coli & LE & 35 & 5 & $38 \pm 0.2$ \\
\hline & $4 \pm 0.3$ & P. aeruginosa & & 30 & & $30 \pm 0.3$ \\
\hline \multirow[t]{2}{*}{ E. hirta (flowers) } & $6 \pm 0.3$ & E. coli & LE & 35 & 5 & $35 \pm 0.2$ \\
\hline & $4 \pm 0.1$ & P. aeruginosa & & 30 & & $30 \pm 0.3$ \\
\hline M. koenigii & - & P. aeruginosa & & 30 & & $30 \pm 0.1$ \\
\hline \multicolumn{7}{|l|}{ Gram-positive bacteria } \\
\hline E. hirta (leaves) & $13 \pm 0.2$ & S. aureus & $\mathrm{L}$ & 29 & 2 & $36 \pm 0.4$ \\
\hline E. hirta (flowers) & $11 \pm 0.5$ & S. aureus & $\mathrm{L}$ & 29 & 2 & $36 \pm 0.2$ \\
\hline M. koenigii & $9 \pm 0.4$ & S. aureus & $\mathrm{L}$ & 29 & 2 & $32 \pm 0.3$ \\
\hline
\end{tabular}

Z.O.I: Zone of inhibition, LE: Levofloxacin, ${ }^{*}$ L: Lincomycin, E. hirta: Euphorbia hirta, M. koenigii: Murraya koenigii, E. coli: Escherichia coli, P. aeruginosa: Pseudomonas aeruginosa, S. aureus: Staphylococcus aureus 
Table 8: Phytochemical analysis of various constituents present in the different extracts

\begin{tabular}{llll}
\hline Plant/components & $\begin{array}{l}\text { E. hirta } \\
\text { (leaves) }\end{array}$ & $\begin{array}{l}\text { E. hirta } \\
\text { (flowers) }\end{array}$ & M. koenigii \\
\hline Steroid & + & + & + \\
Saponin & - & - & + \\
Tannin & + & + & + \\
Protein & - & - & + \\
Terpenoids & + & + & - \\
Carbohydrate & + & + & + \\
Alkaloids & + & + & + \\
Flavonoid & + & + & + \\
Diterpenes & + & + & - \\
Glycosides & + & + & + \\
\hline
\end{tabular}

battling the problem of antibiotic resistance among the microorganisms in the future.

\section{ACKNOWLEDGMENT}

The authors thank Management of Ambala College of Engineering and Applied Research, Ambala, Haryana, India, for providing necessary laboratory facilities to carry out this work.

\section{AUTHORS CONTRIBUTION}

Planning and designing of study: Mukesh Kumar, Vishal Gupta; Experimentation: Divya Gupta; Result Analysis: Mukesh Kumar, Divya Gupta; Manuscript Drafting: Mukesh Kumar, Divya Gupta, Vishal Gupta. All authors contributed in the final approval of manuscript.

\section{CONFLICT OF INTEREST}

The authors declare no conflicts of interest.

\section{REFERENCES}

1. World Health Organization. The Promotion and Development of Traditional Medicine. Geneva: World Health Organization; 1978. Available from: http://www.apps.who.int/medicinedocs/documents/ s7147e/s7147e.pdf. [Last accessed on 2015 May 25].

2. Gupta D, Kumar M. Evaluation of in vitro antimicrobial potential and GC-MS analysis of Camellia sinensis and Terminalia arjuna. Biotechnol Rep 2017;13:19-25.

3. Rawani A, Pal S, Chandra G. Evaluation of antimicrobial properties of four plant extracts against human pathogens. Asian Pac J Trop Biomed 2011;1 Suppl 1:S71-5

4. Leon J, Rojo E, Sanche-Serrano JJ. Wound signalling in plants. J Exp Bot 2001;52 Suppl 354:1-9.

5. Kalemba D, Kunicka A. Antibacterial and antifungal properties of essential oils. Curr Med Chem 2003;10:813-29.

6. Saad B, Azaizeh H, Said O. Tradition and perspectives of Arab herbal medicine: A review. Evid Based Complement Alternat Med 2005;2:475- 9 .

7. Gupta D, Dubey J, Kumar M. Phytochemical analysis and antimicrobial activity of some medicinal plants against selected common human pathogenic microorganisms. Asian Pac J Trop Dis 2016;6 Suppl 1:15-20.

8. Palombo EA. Traditional medicinal plant extracts and natural products with activity against oral bacteria: Potential application in the prevention and treatment of oral diseases. Evid Based Complement Alternat Med 2011;2011:680354.

9. Williamson EM. Major Herbs of Ayurveda. China: Churchill Livingstone; 2002.

10. Kumar S, Malhotra R, Kumar D. Euphorbia hirta: Its chemistry, traditional and medicinal uses, and pharmacological activities. Pharm Rev 2010;4:58-61.

11. Jain V, Momin M, Laddha K. Murraya koenigii: An updated review. Int J Ayurvedic Herbal Med 2012;2 Suppl 4:607-27.
12. Srinivasan K. Plant foods in the management of diabetes mellitus: Spices as beneficial antidiabetic food adjuncts. Int J Food Sci Nutr 2005;56:399-414.

13. Shah KJ, Juvekar AR. Positive inotropic effect of Murraya koenigii (Linn.) spreng extract on an isolated perfused frog heart. Indian J Exp Biol 2006;44:481-4

14. Chessbrough M. Medical Laboratory Manual for Tropical Countries. Oxford: Linacre House; 2000. p. 260.

15. Rojas JJ, Ochoa VJ, Ocampo SA, Muñoz JF. Screening for antimicrobial activity of ten medicinal plants used in Colombian folkloric medicine: A possible alternative in the treatment of nonnosocomial infections. BMC Complement Altern Med 2006;6:2.

16. Jahan F, Lawrence R, Kumar V, Junaid M. Evaluation of antimicrobial activity of plant extracts on antibiotic susceptible and resistant Staphylococcus aureus strains. J Chem Pharm Res 2011;3 Suppl 4:777-9.

17. Bussmann RW, Garcia GM, Glenn A, Sharon D, Chait G, Diaz D, et al. Minimum inhibitory concentrations of medicinal plants used in Northern Peru as antibacterial remedies. J Ethnopharmacol 2010;132 Suppl 1:101-8.

18. Jorgensen JH, Ferraro MJ. Antimicrobial susceptibility testing: A review of general principles and contemporary practices. Clin Infect Dis 2009;49:1749-55.

19. Adwan G, Mhanna M. Synergistic effects of plant extracts and antibiotics on Staphylococcus aureus strains isolated from clinical specimens. Middle East J Sci Res 2008;3 Suppl 3:134-9.

20. Harborne JB. Phytochemical Methods: A guide to Modern Techniques of Plant Analysis. London: Chapman and Hill; 1973.

21. Sofowora A. Screening plants for bioactive agents. In: Medicinal Plants and Traditional Medicinal in Africa. $2^{\text {nd }}$ ed. Ibadan: Spectrum Books Ltd; 1993. p. 134-56.

22. Trease GE, Evans WC. Pharmacognosy. $15^{\text {th }}$ ed. Berlin: Springer; 2002.

23. Ahmad W, Singh S, Kumar S. Phytochemical screening and antimicrobial study of Euphorbia hirta extracts. J Med Plants Stud 2017;5 Supp1 2:183-6.

24. Kumar NS, Simon N. In vitro antimicrobial activity and phytochemical analysis of Murraya koenigii (L) leaf extracts. Glob J Sci Front Res C Biol Sci 2016; 16 Suppl 1:29-32.

25. Perumal S, Mahmud R, Pillai S, Lee WC, Ramanathan S. Antimicrobial activity and cytotoxicity evaluation of Euphorbia hirta (L.) extracts from Malaysia. APCBEE Procedia 2012;2:80-5.

26. Jakhar S, Dahiya P. Antibacterial, antioxidant activity and phytochemical analysis of Euphorbia hirta Linn. Microbiol Res J Int 2017;20 Suppl 2:1-12.

27. Enerva LT, Atienza TV, Glifonea ZR, Villamor OB, Villa NA. Cytotoxicity and antimicrobial property of the leaf extract of Euphorbia hirta (Tawa-Tawa). Open J Soc Sci 2015;3:162-70.

28. Titilope KK, Rashidat EA, Christiana OC, Kehinde ER, Omobolaji JN, Olajide AJ. In-vitro antimicrobial activities of Euphorbia hirta against some clinical isolates. Agric Biol J N Am 2012;3:169-74.

29. Singh G, Kumar P. Antibacterial potential of alkaloids of Withania somnifera L. and Euphorbia hirta L. Int J Pharm Pharm Sci 2012;4 Suppl 1:78-81.

30. Donkor AM, Mensah DO, Fiazorl M. Extracts of Euphobia hirta Linn and Physalis angulata L. And their amalgamation demonstrate potency against Staphylococcus aureus and Pseudomonas aeruginosa. Int J Pharm Pharm Sci 2016;8 Suppl 4:322-6.

31. Kusuma IW, Kuspradini H, Arung ET, Aryani F, Min YH, Kim JS, et al. Biological activity and phytochemical analysis of three Indonesian medicinal plants, Murraya koenigii, Syzygium polyanthum and Zingiber purpurea. J Acupunct Meridian Stud 2011;4:75-9.

32. Alan L, Miller ND. Antioxidant flavonoids: Structure, function and clinical usage. Altern Med Rev 1996;1:103-11.

33. Rupasinghe HP, Jackson CJ, Poysa V, Di Berado C, Bewley JD, Jenkinson J. Soyaapogenol A and B distribution in soybean (Glycine $\max$ L. Merr) in relation to seed physiology, genetic variability and growing location. J Agric Food Chem 2003;51:5888-94

34. Sayyah M, Hadidi N, Kamalinejad M. Analgesic and anti-inflammatory activity of Lactuca sativa seed extract in rats. J Ethnopharmacol 2004;92:325-9.

35. Malairajan P, Gopalakrishnan G, Narasimhan S, Veni JK. Analgesic activity of some Indian medicinal plants. J Ethnopharmacol 2006;19:425-8. 